\title{
Neanderthals, trees and dental calculus: new evidence from El Sidrón
}

\author{
Anita Radini ${ }^{1}$, Stephen Buckley ${ }^{1}$, Antonio Rosas ${ }^{2}$, \\ Almudena Estalrrich ${ }^{2}$, Marco de la Rasilla ${ }^{3} \&$ Karen Hardy ${ }^{4}$
}

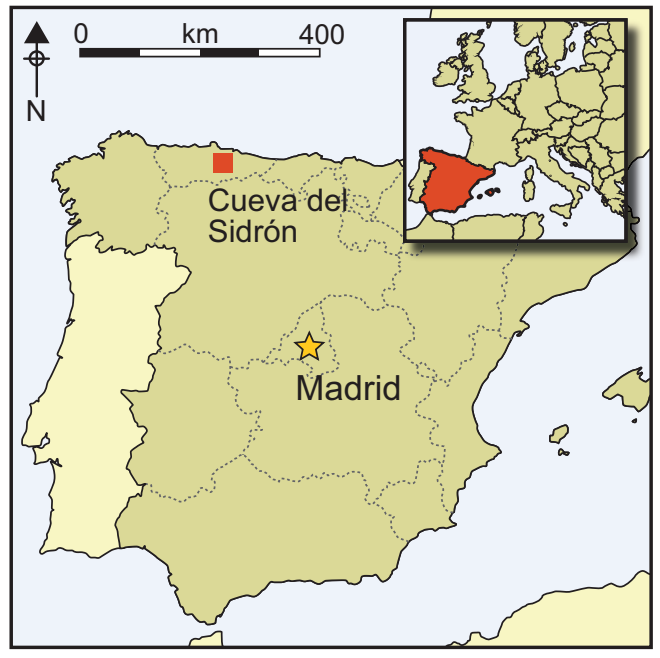

Analysis of dental calculus is increasingly important in archaeology, although the focus has hitherto been on dietary reconstruction. Non-edible material has, however, recently been extracted from the dental calculus of a Neanderthal population from the $49000-$ year-old site of El Sidrón, Spain, in the form of fibre and chemical compounds that indicate conifer wood. Associated dental wear confirms that the teeth were being used for non-dietary activities. These results highlight the importance of dental calculus as a source of wider biographical information, and demonstrate the need to include associated data within research, in particular tooth wear, to maximise this valuable resource.

Keywords: Spain, El Sidrón, Neanderthals, dental calculus, wood, conifer, microscopy, gas chromatography, mass spectrometry

\section{Introduction}

The study of dental calculus from past human and hominin populations is a promising field of investigation, especially for accessing information on plant use in pre-agricultural and non-sedentary populations where other lines of evidence can be poor. Dental calculus is a mineralised deposit of calcium phosphate that adheres to tooth enamel. It is formed by the activity of bacteria, which are energised by salivary sugars to form plaque. If this is not removed, it can calcify in as little as two weeks (Lieverse 1999). This formation process ceases at death because it requires minerals present in the saliva (MacPhee \& Cowley 1975). Once

1 BioArCh, University of York, Biology S Block, Wentworth Way, York YO10 5DD, UK

2 Group of Paleoanthropology MNCN-CSIC, Department of Paleobiology, Museo Nacional de Ciencias NaturalesCSIC, Calle José Gutiérrez Abascal 2, 28006 Madrid, Spain

3 Área de Prehistoria, Department of History, Universidad de Oviedo, Calle Teniente Alfonso Martinez s/n, 33011 Oviedo, Spain

4 ICREA (Catalan Institution for Research and Advanced Studies), Departament de Prehistòria, Facultat de Filosofia i Lletres, Universitat Autònoma de Barcelona, 08193 Bellaterra, Barcelona, Spain (Email: khardy@icrea.cat) 
plaque has calcified, it can survive for extended periods. It is found on teeth in most ancient human populations, and has even been identified on Miocene apes that lived between 8 and 12 million years ago (Hershkovitz et al. 1997). Analyses of material found embedded in ancient dental calculus in human and hominin populations have provided direct evidence of a variety of debris, including human cells and mineralised bacterial structures (Hardy et al. 2012, in press; Buckley et al. 2014; Warinner et al. 2014).

Previous studies have mainly focused on dietary reconstruction, and the majority of the finds have been interpreted as the remains of the deliberate consumption of plant-derived food (Henry \& Piperno 2008; Piperno \& Dillehay 2008; Hardy et al. 2009; Li et al. 2010; Weslowski et al. 2010; Henry et al. 2012, 2014; Mickleburgh \& Pagán-Jiménez 2012). Several studies have, however, highlighted non-nutritional information from dental calculus, including evidence for both non-masticatory use of the teeth and the presence of inhaled or unconsciously ingested material (Blondiaux \& Charlier 2008; Blatt et al. 2011; Hardy et al. 2012, in press; Buckley et al. 2014; although see Weslowski et al. 2010 for an alternative interpretation). Here, we present evidence in the form of chemical compounds and non-dietary debris from non-edible material recovered in the dental calculus of the Neanderthal population at El Sidrón, northern Spain. An earlier study of this material revealed evidence for consumption of cooked starchy plant food, exposure to wood smoke, the presence of bitumen and the use of two non-nutritional plants; due to their medicinal qualities, ingestion of these plants was interpreted as evidence for self-medication (Hardy et al. 2012, 2013).

\section{Materials and methods}

The Neanderthal fossil assemblage from El Sidrón is dated to approximately 49 kya (Wood et al. 2013). The minimum number of individuals identified at the site is currently 13 (Rosas et al. 2013), including seven adults (three female, three male, one unidentified), three adolescents (two male, one possible female), two juveniles (one male) and one infant (Lalueza-Fox et al. 2011; Rosas et al. 2012, 2013). The analysis of non-masticatory dental wear has revealed that all individuals were right-handed (Estalrrich \& Rosas 2013) and all used their mouth as a third hand (Estalrrich \& Rosas 2015).

Dental calculus was extracted from five adult individuals, and the samples were degraded and examined for their surviving content. Optical microscopy was used for the microfossil material, and the samples were also analysed using sequential thermal desorption-gas chromatography-mass spectrometry (TD-GC-MS) and pyrolysis-gas chromatography mass spectrometry (Py-GC-MS) (Hardy et al. 2012). A second study, focused on the evidence for non-edible material, was conducted using a Zeiss compound microscope with magnifications up to $\times 800$, at the Ancient Starch Laboratory, University of Leicester, using the original mounted microscope slides.

\section{Results}

A fragment of non-edible conifer wood tissue with a small fleck of dental calculus still attached to it (Figure 1B) was identified from the material extracted from the lower left 


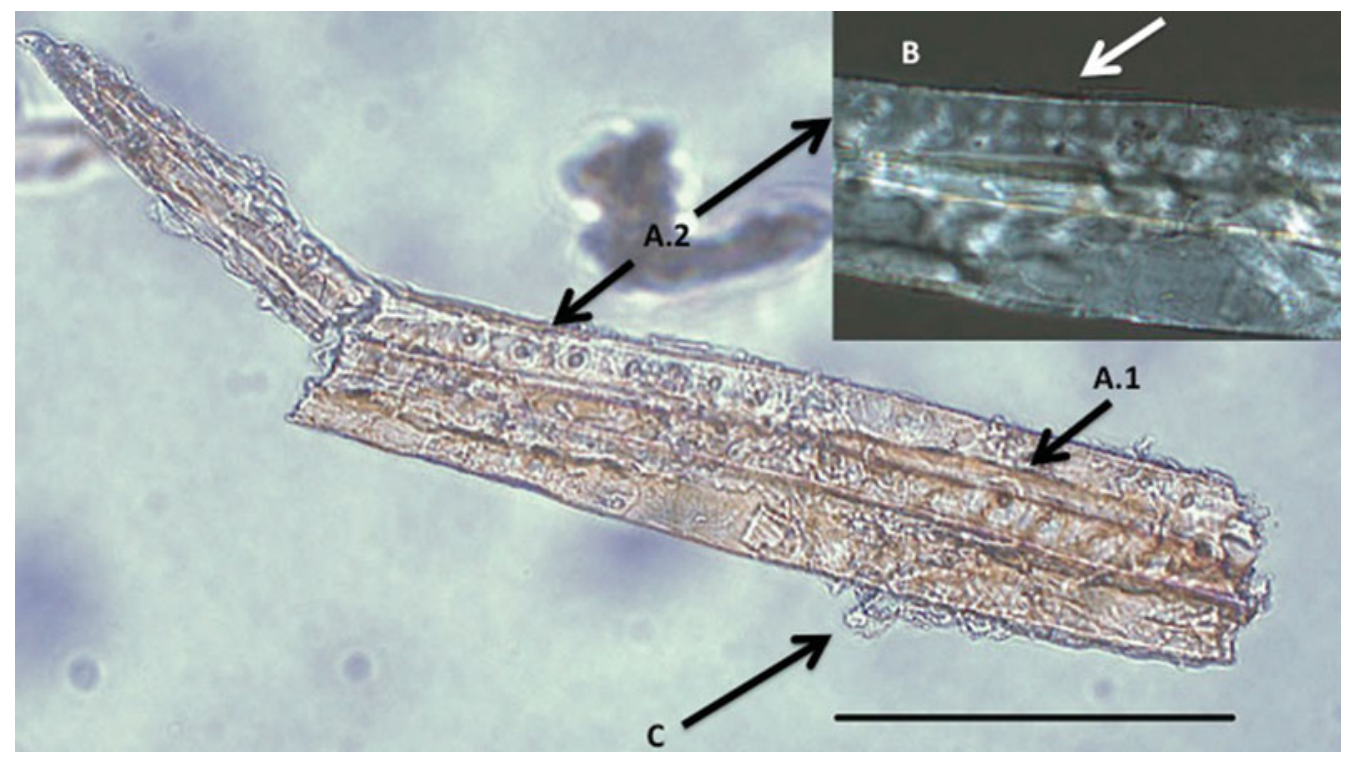

Figure 1. Physical evidence: fragment of wood tissue, consisting of lines of tracheids with lines of bordered pits (A.1 and A.2); the 'cross' feature is visible under cross polarised light (B), and small flecks of calculus are still attached (C); scale bar = $100 \mu \mathrm{m}$.

first molar (LLM1) of sample 1327h (adult 5), a right-handed (Estalrrich \& Rosas 2013) adult female (Lalueza-Fox et al. 2011; Rosas et al. 2012, 2013). The fragment of un-charred conifer wood measures $285 \mu \mathrm{m}$ in length and is $40 \mu \mathrm{m}$ at its widest point, which makes it relatively large compared with other debris retrieved from this and other studies (e.g. Hardy et al. 2012, in press; Buckley et al. 2014; Warinner et al. 2014). Identifying features include the visible remains of xylem, which consist of tracheids (tubular cells) with parallel lines of small, regular, circular bordered pits that often display a 'cross' feature in cross polarised light. These are present along the length of the fibrous material, and are consistent with conifer 'soft wood' (Gerola 1988) (Figure 1). The sample cannot therefore be confused with other (edible) parts, or other species of conifer trees, and its ingestion is thus not related to diet. Other non-starchy debris observed in samples from all of the individuals studied include non-diagnostic plant remains comprising long fibres similar to those found in plant stems, mineral grit and soil flecks, all still partially embedded in the calculus matrix. This suite of remains is similar to those found in other studies (Buckley et al. 2014; Warinner et al. 2014).

The chemical results indicated that conifer wood occurred in all three of the samples examined by TD-GC-MS and Py-GC-MS. Samples SD1604 (adult 4, right-handed, young adult female) and SDR007 (adult 2, right-handed, young male) had tentative evidence for dehydroabietic acid and 7-oxo-dehydroabietic acid, two specific markers for conifers. Identifications were based on both the retention times and mass spectra when compared to reference samples containing these two diterpenoids under identical analytical conditions. A tentative identification of retene from the Py-GC-MS may suggest heated conifer resin

(C) Antiquity Publications Ltd, 2016 


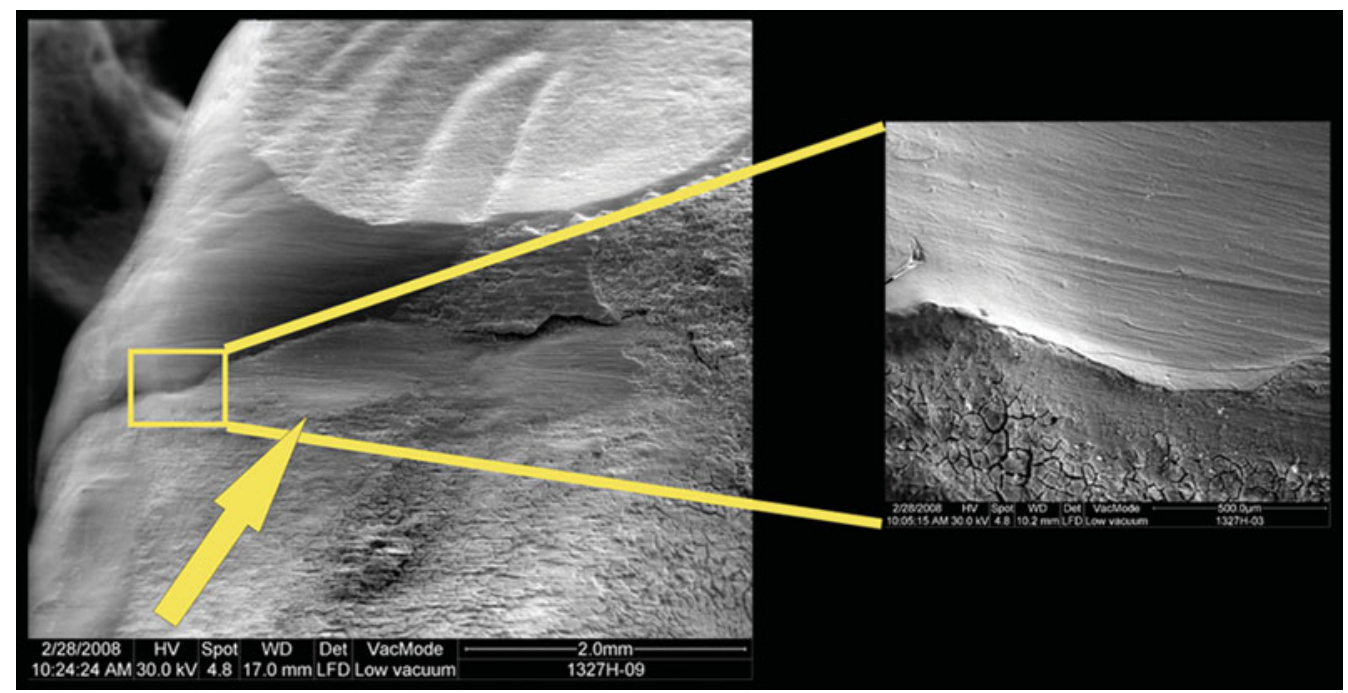

Figure 2. Interproximal groove on the distal side from LLM1 SD-1327i belonging to an El Sidrón individual, adult 5; although the groove is not well developed, numerous fine and parallel micro scratches are observable on the surface.

in sample SDR007. Sample SD1217 (adult 3, right-handed, female) had very tentative evidence for dehydroabietic acid and 7-oxo-dehydroabietic acid, although no conifer markers indicative of heating were present. Biomolecular studies of dental calculus are highly challenging as the entrapped organic material is variable and the quantities are often small, yet despite this, while all these conifer markers are tentative, they occur in all three samples, and, taken together, present a solid case for the presence of conifer.

\section{Discussion: contextualising the results}

Accidental ingestion and extra-masticatory uses of teeth

The most common ways in which material can enter the mouth and become embedded in dental calculus are: food and drink, inhalation, use of the mouth as a third hand, oral hygiene activities or direct contamination from hand to mouth. Particles of up to $70 \mu \mathrm{m}$ (microns) in size are inhaled through the mouth in most circumstances, while larger particles can also be inhaled in certain conditions (Se et al. 2010). Pollen, phytoliths, transient starch granules, microcharcoal, soot, grit and dust are all airborne particles that fall within this size range and can be inhaled (Schäppi et al. 1999; Laurence et al. 2011).

The most common evidence for the non-masticatory use of teeth in archaeological samples is based on tooth wear and attrition. This type of evidence is widespread and can be found across the geographic and temporal spectra (Hinton 1981; Ryan \& Johansen 1989; Bonfiglioli et al. 2004; Eshed et al. 2006; Lozano et al. 2009; Volpato et al. 2012). Ethnographic evidence for the use of teeth for non-masticatory purposes is also very common. Kreuger and Ungar (2012) provide a summary of recorded uses of anterior teeth among North American and Arctic populations, including chewing raw materials such 
as leather, wood and root fibres, as well as grasping or holding materials as they are being worked. In Papua New Guinea, plant fibres were sometimes chewed to soften them before making string (MacKenzie 1991).

Non-masticatory tooth wear has been found widely in many Neanderthal populations (Clement et al. 2012), including El Sidrón (Estalrrich \& Rosas 2013, 2015). Most of the heavy wear thought to result from using the teeth as a third hand is found on the anterior teeth, with little evidence for this on teeth behind the canines (Clement et al. 2012). Fiorenza et al. (2011) differentiate between anterior teeth, used principally as a third hand for holding, and posterior teeth used for conducting tasks. Lozano et al. (2008) also identify evidence for holding, pulling or handling on anterior teeth from Sima de los Huesos, Atapuerca, and note less evidence for non-masticatory wear on canines and pre-molars. In several cases, the distribution of the microwear (in this case, labial scratches) has demonstrated the handedness of the individuals. The proportions of right- to left-handedness correspond with that found today, as is seen on a contemporary basis (Estalrrich \& Rosas 2013; Lozano et al. 2013), and also with a gendered division of labour among individuals from the same group (Estalrrich $\&$ Rosas 2015). This study has revealed that while all individuals have cultural striations, those detected on adult female teeth were longer than those found on adult male teeth. The differences detected on the overall activity-related dental wear pattern suggest a division of labour by age and sex in Neanderthals for use of the mouth as a third hand (Estalrrich $\&$ Rosas 2015). Finally, and potentially relevant in the context of the current findings, interproximal grooves are very common in prehistoric populations, and have been found on teeth from Homo habilis and all subsequent hominin species (Puech \& Gianfarani 1988), including Neanderthals from many different sites (Frayer \& Russell 1987; Formicola 1988; Smith et al. 2006; Urbanowski et al. 2010; Rosas et al. 2011; Lozano et al. 2013). They are thought to be the result of oral hygiene activities (Brothwell 1963), possibly a result of tooth picking (Ungar et al. 2001), as is common today among traditional communities, who use a wide range of plant materials for this purpose. Some higher primate groups have also been observed using items to pick or rub their teeth. The chewing of resin has been recorded ethnographically, and lumps of birch bark and pine resin have been found on some Scandinavian Mesolithic sites (Hardy in press). Materials suggested for use as tooth picks include wood, bone, sinew and grass (Eckhardt \& Piermarini 1988; Brown \& Molnar 1990; Hlusko 2003). A small number of the El Sidrón teeth had interproximal or tooth-pick grooves, including tooth SD $1327 \mathrm{i}$ (LM2), which is adjacent to SD $1327 \mathrm{~h}$ (LM1) in adult 5 (Rosas et al. 2011; Figures $2 \&$ 3), from which the wood fragment was recovered.

\section{Neanderthals and trees}

Gymnosperms, in particular conifers, are very widespread and occur in temperate regions across the world, where they are frequently the dominant species. Conifer wood is useful as firewood; it is easy to light due to its abundant resin, although the wood tends to spark and burn quite fast. The inner bark can also be used to make cordage. Most conifer trees have several parts that are edible, including the needles, nuts and

(C) Antiquity Publications Ltd, 2016 


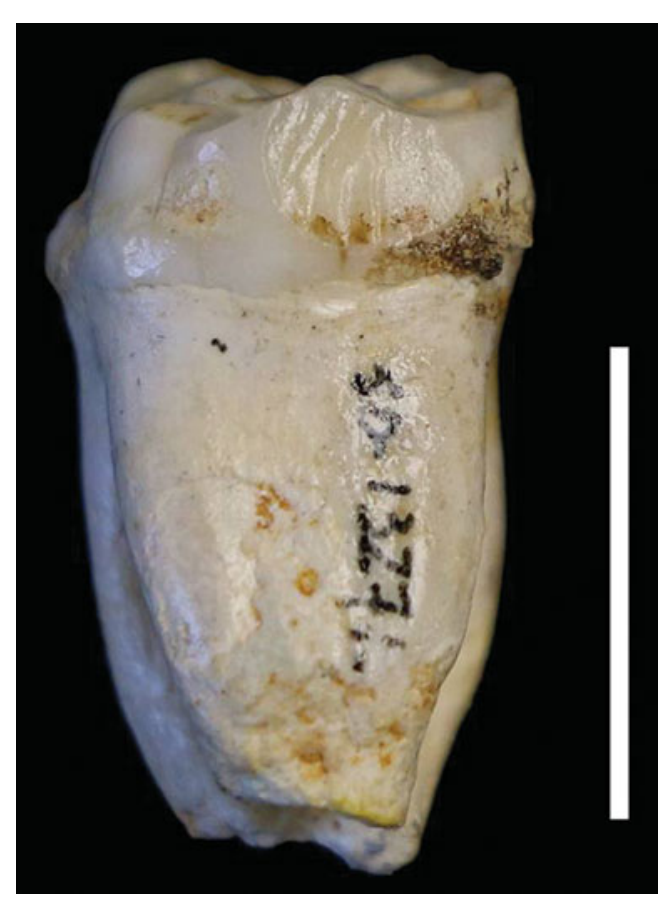

Figure 3. Photographic image of the interproximal side with the incipient groove (polished area on the enamel-dentine junction) of SD-1327h (LLM1) from El Sidrón adult 5; scale bar $=1 \mathrm{~cm}$. inner bark, while the resins can be medicinal. There is abundant ethnographic evidence to demonstrate the use of the inner bark of Scots pine (Pinus sylvestris L.) among the Saami people in northern Sweden, as food (Niklasson et al. 1994) and raw materials (Zackrisson et al. 2000). As well as being edible, the resins have adhesive qualities and can be used in the preparation of pitch. Conifer wood is today used mostly as a raw material and as fuel. Many conifer resins have medicinal and antibacterial qualities that may have been appreciated by $\mathrm{Ne}$ anderthal populations (Hardy et al. 2012, 2013). A small number of conifer trees, most notably from the Taxaceae or yew family, are poisonous, although these also have medicinal qualities. Among the many conifers native to Spain, the silver fir (Abies alba Mill.) has edible inner bark with antiseptic qualities, and the dark mountain pine (Pinus mugus Turra) has an antiseptic resin.

The most abundant evidence for use of wood by Neanderthals is in the form of charcoal remains from hearths, and there is extensive evidence for this across a broad area (e.g. Roebroeks \& Villa 2011; Albert et al. 2012; Aldeias et al. 2012). Evidence is also abundant in Iberia, including at Bolomor Cave, which has some of the earliest hearths in southern Europe (Fernández Peris et al. 2012), and at Abri Romani, where pine charcoal (Burjachs et al. 2011) and complex and sophisticated fire-making techniques (Courty et al. 2012) have been identified. Pine charcoal has been identified at Gorham's Cave, Gibraltar, dated to around 44000 BP (Finlayson et al. 2001), while Badal et al. (2011) have identified conifers, principally pine and juniper, in charcoal from three Iberian Neanderthal sites. Charred pine seeds from a Neanderthal context were found at Gorham's Cave, Gibraltar (Barton 2000), and may have been collected and roasted as food, while Sandgathe and Hayden (2003) suggest that pointed artefacts found on several Neanderthal sites may have been used to obtain edible inner bark.

There is evidence that Neanderthals also manufactured pitch. Pitch can be obtained from a range of trees including conifers, yet its manufacture is a relatively complex technological process that requires an understanding of the raw material properties of trees. The earliest evidence for the use of resin-based pitch is from a Mid-Pleistocene site in Italy (Mazza et al. 2006) where chemical evidence for resins of Betulaceae origin was found on a series of flakes. Birch-bark pitch was also identified at Konigsaue, Germany, dating to 43000-48500 BP (Grünberg 2002). Bitumen, an analogous and alternative product to tree-based pitch, which was found to have been highly heated, has been 
found adhered to stone tools at Umm el Tlel, dated to around $40 \mathrm{kya}$ (Boëda et al. 1996).

Early evidence for wood as a raw material includes one artefact that may have been modified from the $790 \mathrm{kya}$ site of Gesher Benot Ya'aqov in Israel (Goren-Inbar et al. 2002). A spear tip made of yew found in Clacton-on-Sea, England, has been dated to 450 kya (Oakley et al. 1977). Three spears made of wood from the conifer species Abies alba (common silver fir) were found at Schöningen, Germany, and date to around $400 \mathrm{kya}$ (Thieme 1997), although a re-evaluation of these dates is currently underway (Balter 2014). The earliest wooden artefact attributed to Neanderthals is a spear point from Lehringen dating to between 120 and 125 kya (Langley et al. 2008). This combined evidence for woodworking, together with the use-wear on stone tools (Rots 2013), and the increasing number of sites where the use of bitumen or pitch for hafting has been identified, suggests Neanderthals had a detailed applied knowledge of trees and wood.

Chemical evidence from the dental calculus of sample SDR-007c (adult 2, young male) from El Sidrón indicates the presence of both bitumen and conifer 'resin'. The bitumen (natural petroleum/oil) was identified by the presence of characteristic hopanes (Hardy et al. 2012). The conifer tree 'resin' that is also present is shown by the diagnostic diterpenoids dehydroabietic acid and 7-oxo-dehydroabietic acid, which confirm a conifer source: either the tree resin exudate or, perhaps more probable given the conifer wood fibre identified, conifer wood or bark, which also contain these diterpenoid components. This sample also has activity-related dental wear that is unusual within this population with an elevated incidence of chipped enamel. This has been considered to indicate an exceptionally specialised behaviour (Estalrrich \& Rosas 2015); the chemical evidence for bitumen and resin reinforces this uniqueness.

The presence of minerals and soil flecks suggests dirt. The conifer fragment and the chemical markers for conifer, as well as the items suggestive of dirt, could have reached the mouth and become embedded in the dental calculus through a variety of non-dietary pathways, including inhalation, dirty food, raw material processing, oral hygiene activities, or simply via dirty hands or material placed in the mouth. Dust generated by woodworking could have entered the mouth during oral breathing, and during eating as settled dust on food items. The processing of plants as raw materials can comprise various stages, including holding the plant material by the teeth and/or chewing it for splitting and softening; any of these activities can potentially leave material traces in the dental calculus.

\section{Conclusions}

Dental calculus studies are becoming increasingly important in archaeology, although there is a tendency to focus on the dietary evidence (Blondiaux \& Charlier 2008). Nondietary pathways to the inclusion of the micro-debris in calculus are, however, equally plausible (Radini et al. 2016). In this study, we have combined the evidence from microscopy and chemical analysis to demonstrate the presence of non-edible conifer wood within the mouth. The dental wear, in particular in the case of adult 2 (young male; SDR-007c), confirms the use of the teeth for non-diet related activities. Taken together, the evidence for conifer wood and the other small debris extracted highlight the need to

(C) Antiquity Publications Ltd, 2016 
consider a wide range of potential pathways, unrelated to food, through which material can become embedded in dental calculus. This is particularly significant where there is persistent evidence of non-dietary uses of teeth, as is the case among Neanderthals. Likewise, evidence for oral hygiene activities is widespread, and there is physical evidence, in the form of interproximal grooves, that suggests Neanderthals habitually rubbed material between their teeth.

We believe that these results represent the first physical evidence for non-edible debris found 'in the mouth' of a Neanderthal individual. Although we cannot be certain whether the material represents oral hygiene activity or use of the mouth as a third hand or indeed accidental inhalation or ingestion, its presence confirms that material unrelated to diet can be found in dental calculus. A broad approach to entrapped material, which incorporates this perspective, offers an opportunity to explore a wide range of hitherto unimagined biographical detail related to past human and hominin populations.

\section{Acknowledgements}

Research and fieldwork at the El Sidrón site is funded by the Principado de Asturias and the Spanish Government (Project CGL2012-36682). The chemical analysis was conducted at Pharos Research, UK. Efthymia Nikita and Hayley McParland are also thanked.

\section{References}

Albert, R.M., F. Berna \& P. Goldberg. 2012. Insights on Neanderthal fire use at Kebara Cave (Israel) through high-resolution study of prehistoric combustion features: evidence from phytoliths and thin sections. Quaternary International 247: 278-93. http://dx.doi.org/10.1016/j.quaint.2010.10.016

Aldeias, V., P. Goldberg, D. Sandgathe, F. Berna, H.L. Dibble, S.P. McPherron, A. Turq \& Z. REZEK. 2012. Evidence for Neandertal use of fire at Roc de Marsal (France). Journal of Archaeological Science 39: 2414-23. http://dx.doi.org/10.1016/j.jas.2012.01.039

Badal, E., V. VillaVerde \& J. Zilhão. 2011. The fire of Iberian Neanderthals. Wood charcoal from three new Mousterian sites in the Iberian Peninsula. SAGVNTVM Extra 11: 77-78.

BALTER, M. 2014. The killing ground. Science 344: $1080-83$. http://dx.doi.org/10.1126/science.344.6188.1080

BARTON, R.N.E. 2000. Mousterian hearths and shellfish: late Neanderthal activities in Gibraltar, in C.B. Stringer, R.N.E. Barton \& J.C. Finlayson (ed.) Neanderthals on the edge: $150^{\text {th }}$ anniversary conference of the Forbes' Quarry discovery, Gibraltar: 211-20. Oxford: Oxbow.
Blatt, S.H., B.G. Redmond, V. CASSMan \& P.W. SCIULLI. 2011. Dirty teeth and ancient trade: evidence of cotton fibres in human dental calculus from Late Woodland, Ohio. International Journal of Osteoarchaeology 21: 669-78. http://dx.doi.org/10.1002/oa.1173

Blondiaux, J. \& P. Charlier. 2008. Palaeocytology in skeletal remains: microscopic examination of putrefaction fluid deposits and dental calculus of skeletal remains from French archaeological sites. International Journal of Osteoarchaeology 18: 1-10. http://dx.doi.org/10.1002/oa.931

BoËda, E., J. CONNAN, D. Dessort, S. MuHESEn, N. Mercier, H. Valladas \& N. Tisnérat. 1996. Bitumen as a hafting material on Middle Palaeolithic artefacts. Nature 380: 336-38. http://dx.doi.org/10.1038/380336a0

Bonfiglioli, B., V. Mariotti, F. Facchini, M.G. Belcastro \& S. Condemi. 2004 Masticatory and non-masticatory dental modifications in the Epipalaeolithic necropolis of Taforalt (Morocco). International Journal of Osteoarchaeology 14: 448-56. http://dx.doi.org/10.1002/oa.726

BROTHWELL, D.R. 1963. The macroscopic dental pathology of some earlier human populations, in D.R. Brothwell (ed.) Dental anthropology: 27-88. Oxford: Pergamon. 
Brown, T. \& S. MOLnar. 1990. Interproximal grooving and task activity in Australia. American Journal of Physical Anthropology 81: 545-53. http://dx.doi.org/10.1002/ajpa.1330810410

BuCKLEY, S., D. USAI, T. JAKOB, A. RADINI \& K. HARDY. 2014. Dental calculus reveals unique insights into food items, cooking and plant processing in prehistoric central Sudan. PLOS ONE 9(7): e100808. http://dx.doi.org/10.1371/journal.pone.0100808

Burjachs, F., J.M. LÓpez-García, E. Allué, H.A. Blain, F. Rivals, H. BENNÀsar \& I. ExPÓSITO. 2011. Palaeoecology of Neanderthals during Dansgaard-Oeschger cycles in northeastern Iberia (Abric Romaní): from regional to global scale. Quaternary International 247: 26-37. http://dx.doi.org/10.1016/j.quaint.2011.01.035

Clement, A.F., S.W. Hillson \& L.C. Aiello. 2012. Tooth wear, Neanderthal facial morphology and the anterior dental loading hypothesis. Journal of Human Evolution 62(3): 367-76. http://dx.doi.org/10.1016/j.jhevol.2011.11.014

Courty, M.A., E. Carbonell, J. Vallverdú Poch \& R. BANERJEE. 2012. Microstratigraphic and multi-analytical evidence for advanced Neanderthal pyrotechnology at Abric Romani (Capellades, Spain). Quaternary International 247: 294-312. http://dx.doi.org/10.1016/j.quaint.2010.10.031

ECKHARDT, R.B. \& A.L. PIERMARINI. 1988. Interproximal grooving of teeth: additional evidence and interpretation. Current Anthropology 49: 663-71.

Eshed, V., A. Gopher \& I. Hershkovitz. 2006. Tooth wear and dental pathology at the advent of agriculture: new evidence from the Levant. American Journal of Physical Anthropology 130: 145-59. http://dx.doi.org/10.1002/ajpa.20362

Estalrrich, A. \& A. Rosas. 2013. Handedness in Neandertals from the El Sidrón (Asturias, Spain): evidence from instrumental striations with ontogenetic inferences. PLoS ONE 8(5): e62797. http://dx.doi.org/10.1371/journal.pone.0062797

- 2015. Division of labor by sex and age in Neandertals: an approach through the study of activity-related dental wear. Journal of Human Evolution 80: 51-63. http://dx.doi.org/10.1016/j.jhevol.2014.07.007

Fernández Peris, J., V.B. González, R. Blasco, F. Cuartero, H. Fluck, P. Sañudo \& C. VerdasCO. 2012. The earliest evidence of hearths in Southern Europe: the case of Bolomor Cave (Valencia, Spain). Quaternary International 247: 267-77. http://dx.doi.org/10.1016/j.quaint.2010.10.014

Finlayson, C., R. Barton \& C. Stringer. 2001. The Gibraltar Neanderthals and their extinction. Les premiers hommes modernes de la Péninsule Ibérique. Trabalhos de Arqueologia 17: 117-22.
Fiorenza, L., S. Benazzi \& O. Kullmer. 2011. Para-masticatory wear facets and their functional significance in hunter-gatherer maxillary molars. Journal of Archaeological Science 38: 2182-89. http://dx.doi.org/10.1016/j.jas.2011.03.012

FORMICOLA, V. 1988. Interproximal grooving of teeth: additional evidence and interpretation. Current Anthropology 29: 663-71. http://dx.doi.org/10.1086/203686

Frayer, D.W. \& M.D. Russell. 1987. Artificial grooves on the Krapina Neanderthal teeth. American Journal of Physical Anthropology 74: 393-405.

GEROLA, F.M. 1988. Biologia vegetale: sistematica filogenetica. Torino: Unione Tipografico Editrice Torinese.

Goren-Inbar, N., E. Werker \& C.S. Feibel. 2002. The Acheulian site of Gesher Benot Ya'aqov, Israel. The wood assemblage. Oxford: Oxbow.

GrÜnberG, J. 2002. Middle Palaeolithic birch-bark pitch. Antiquity 76: 15-16. http://dx.doi.org/10.1017/S0003598X00089638

HaRdY, K. In press. Plants as raw materials, in K. Hardy \& L. Kubiak Martens (ed.) Wild harvest: plants in the Hominin and pre-agrarian human worlds. Oxford: Oxbow.

Hardy, K., A. Blakeney, L. Copeland, J. Kirkham, R.W. Wrangham \& M. Collins. 2009. Starch granules, dental calculus and new perspectives on ancient diet. Journal of Archaeological Science 36: 248-55. http://dx.doi.org/10.1016/j.jas.2008.09.015

Hardy, K., S. Buckley, M.J. Collins, A. Estalrrich, D.R. BRothWell, L. Copeland,

A. García-Tabernero, S. García-Vargas, M. De la Rasilla, C. Lalueza-Fox, R. Huguet, M. Bastir, D. Santamaría, M. Madella, J. Wilson, A. Cortés \& A. Rosas. 2012. Neanderthal medics? Evidence for food, cooking, and medicinal plants entrapped in dental calculus. Naturwissenschaften 99: 617-26. http://dx.doi.org/10.1007/s00114-012-0942-0

Hardy, K., S. Buckley \& M. HuffMan. 2013. Neanderthal self-medication in context. Antiquity 337: 873-78. http://dx.doi.org/10.1017/S0003598X00049528

Hardy, K., A. Radini, S. Buckley, R. Sarig, A. Gopher \& R. BARKAI. In press. Dental calculus reveals potential respiratory irritants and ingestion of essential plant-based nutrients at Lower Palaeolithic Qesem Cave Israel. Quaternary International. http://dx.doi.org/10.1016/j.quaint.2015.04.033

(C) Antiquity Publications Ltd, 2016 


\section{Neanderthals and trees}

Henry, A.G. \& D.R. Piperno. 2008. Using plant microfossils from dental calculus to recover human diet: a case study from Tell al-Raqā’i, Syria. Journal of Archaeological Science 35: 1943-50. http://dx.doi.org/10.1016/j.jas.2007.12.005

Henry, A.G., P.S. Ungar, B.H. Passey, M. SPONHEIMER, L. RosSOUW, M. BAMFORD, D.J. Deruiter \& L. Berger. 2012. The diet of Australopithecus sediba. Nature 487: 90-93. http://dx.doi.org/10.1038/ nature 11185

Henry, A.G., A.S. Brooks \& D.R. Piperno. 2014. Plant foods and the dietary ecology of Neanderthals and early modern humans. Journal of Human Evolution 69: 44-54. http://dx.doi.org/10.1016/j.jhevol.2013.12.014

Hershkovitz, I., J. Kelly, B. Latimer, B.M. RothsChild, S. Simpson, J. POLAK $\&$ M. Rosenberg. 1997. Oral bacteria in Miocene Sivapithecus. Journal of Human Evolution 33: 507-12. http://dx.doi.org/10.1006/jhev.1997.0149

HiNTON, R.J. 1981. Form and patterning of anterior tooth wear among aboriginal human groups. American Journal of Physical Anthropology 54: 555-64. http://dx.doi.org/10.1002/ajpa.1330540409

HLusKo, L.J. 2003. The oldest hominid habit? Experimental evidence for toothpicking with grass stalks. Current Anthropology 44: 738-41. http://dx.doi.org/10.1086/379263

Krueger, K.L. \& P.S. Ungar. 2012. Anterior dental microwear texture analysis of the Krapina Neandertals. Central European Journal of Geosciences 4: 651-62. http://dx.doi.org/10.2478/s13533-012-0111-1

Lalueza-Fox, C., A. Rosas, A. Estalrrich, E. Gigli, A. García-Tabernero, S. García-VARgas, F. SÁnchez-Quinto, O. Ramírez, S. Civit, M. Bastir, R. Huguet, D. Santamaría \& M. DE LA RASILLA. 2011. Genetic evidence for patrilocal mating behaviour among Neandertal groups. Proceedings of the National Academy of Sciences of the USA 108: 250-53. http://dx.doi.org/10.1073/pnas.1011553108

LANGley, M.C., C. Clarkson \& S. Ulm. 2008. Behavioural complexity in Eurasian Neanderthal populations: a chronological examination of the archaeological evidence. Cambridge Archaeological Journal 18: 289-307. http://dx.doi.org/10.1017/S0959774308000371

Laurence, A.R., A.V. Thoms, V.M Bryant \& C. McDonough. 2011. Airborne starch granules as a potential contamination source at archaeological sites. Journal of Ethnobiology 31: 213-32.

http://dx.doi.org/10.2993/0278-0771-31.2.213
LI, M.Q., X.Y. YANG, H. WANG, Q. WANG, X. JiA \& Q.S. GE. 2010. Starch grains from dental calculus reveal ancient plant foodstuffs at Chenqimogou site, Gansu Province. Science China Earth Sciences 53: 694-99. http://dx.doi.org/10.1007/s11430-010-0052-9

LIEVERSE, A.R. 1999. Diet and the aetiology of dental calculus. International Journal of Osteoarchaeology 9: 219-32.

http://dx.doi.org/10.1002/(SICI)1099-1212 (199907/08)9:4<219::AID-OA475>3.0.CO;2-V

Lozano, M., J.M. BERMúdez de Castro,

E. Carbonell \& J.L. Arsuaga. 2008.

Non-masticatory uses of anterior teeth of Sima de los Huesos individuals (Sierra de Atapuerca, Spain). Journal of Human Evolution 55: 713-28. http://dx.doi.org/10.1016/j.jhevol.2008.04.007

Lozano, M., M. Mosquera, J.M.B. de Castro, J.L. Arsuaga \& E. CARbonell. 2009. Right-handedness of Homo heidelbergensis from Sima de los Huesos (Atapuerca, Spain) 500,000 years ago. Evolution and Human Behavior 30: 369-76. http://dx.doi.org/10.1016/ j.evolhumbehav.2009.03.001

Lozano, M., M.E. SubirA, J. Aparicio, C. Lorenzo \& G. GÓmEZ-Merino. 2013. Toothpicking and periodontal disease in a Neanderthal specimen from Cova Foradà site (Valencia, Spain). PLoS ONE 8(10): e76852. http://dx.doi.org/10.1371/journal.pone.0076852

MaCPHeE, T. \& G. CoWley. 1975. Essentials of periodontology and periodontics. Oxford: Blackwell Scientific.

MACKeNZIE, M. 1991. Androgynous objects: string bags and gender in central New Guinea. Philadelphia (PA): Harwood Academic.

Mazza, P.P.A., F. Martini, B. Sala, M. Magi, M.P. Colombini, G. Giachi, F. Landucci, C. Lemorini, F. Modugno \& E. Ribechini. 2006. A new Palaeolithic discovery: tar-hafted stone tools in a European Mid-Pleistocene bone-bearing bed. Journal of Archaeological Science 33: 1310-18. http://dx.doi.org/10.1016/j.jas.2006.01.006

Mickleburgh, H.L. \& J.R. PAGÁN-Jiménez. 2012. New insights into the consumption of maize and other food plants in the pre-Columbian Caribbean from starch grains trapped in human dental calculus. Journal of Archaeological Science 39: 2468-78.

http://dx.doi.org/10.1016/j.jas.2012.02.020

NikLasson, M., O. ZaCKRISSON \& L. ÖsTLUnd. 1994. A dendroecological reconstruction of use by Saami of Scots pine (Pinus sylvestris L.) inner bark over the last 350 years at Sädvajaure, N. Sweden. Vegetation History and Archaeobotany 3: 183-90. http://dx.doi.org/10.1007/BF00202025 
OAKley, K.P., P. Andrews, L.H. Keeley \& J.D. ClarK. 1977. A reappraisal of the Clacton spearpoint. Proceedings of the Prehistoric Society 43: 13-30. http://dx.doi.org/10.1017/S0079497X00010343

PiPERNO, D.R. \& T.D. Dillehay. 2008. Starch grains on human teeth reveal early broad crop diet in northern Peru. Proceedings of the National Academy of Sciences of the USA 105: 19622-27. http://dx.doi.org/10.1073/pnas.0808752105

PUECH, P.F. \& F. GIANFARANI. 1988. Interproximal grooving of teeth: additional evidence and interpretation. Current Anthropology 29: 663-71. http://dx.doi.org/10.1086/203686

RAdini, A., E. NikiTA \& L.-M. SHILlito. 2016. Human dental calculus and a medieval urban environment, in B. Jervis, L. Broderick \& I. Grau-Sologestoa (ed.) Everyday life in medieval Europe: environmental and artefactual approaches to dwelling in town and country. Belgium: Brepols. http://dx.doi.org/10.1073/pnas.1018116108

Roebroeks, W. \& P. Villa. 2011. On the earliest evidence for the habitual use of fire in Europe. Proceedings of the National Academy of Sciences of the USA 108: 5209-14. http://dx.doi.org/10.1073/pnas.1018116108

Rosas, A., A. Estalrrich, S. García-Vargas, A. García-Tabernero, M. Bastir, R. Huguet \& A. Peña-Melian. 2011. Los fósiles neandertales de la cueva de El Sidrón, in M. de la Rasilla, A. Rosas, J.C. Cañaveras \& C. Lalueza-Fox (ed.) La cueva de El Sidrón (Borines, Piloña, Asturias). Investigación interdisciplinar de un grupo neanderta: 81-116. Oviedo: Gobierno del Principado de Asturias.

Rosas, A., A. Estalrrich, A. García-Tabernero, M. Bastir, S. García-Vargas,

A. SÁnchez-Meseguer, R. Huguet,

C. Lalueza-Fox, A. Peña-Melián, E. Kranioti, D. Santamaría, M. de la Rasilla \& J. Fortea. 2012. Les Néandertaliens d'El Sidrón (Asturies, Espagne). Actualisation d'un nouvelé chantillon. L'Anthropologie 116: 57-76. http://dx.doi.org/10.1016/j.anthro.2011.12.003

Rosas, A., A. Estalrrich, S. García-Vargas, A. García-Tabernero, R. Huguet, C. Lalueza-Fox \& M. DE la Rasilla. 2013. Identification of Neandertal individuals in fragmentary fossil assemblages by means of tooth associations: the case of El Sidrón (Asturias, Spain). Comptes Rendus Palevol 12: 279-91. http://dx.doi.org/10.1016/j.crpv.2013.06.003

RoTs, V. 2013. Insights into early Middle Palaeolithic tool use and hafting in Western Europe. The functional analysis of level IIa of the early Middle Palaeolithic site of Biache-Saint-Vaast (France). Journal of Archaeological Science 40: 497-506. http://dx.doi.org/10.1016/j.jas.2012.06.042
RYAN, A.S. \& D.C. JoHANSON. 1989. Anterior dental microwear in Australopithecus afarensis: comparisons with human and non-human primates. Journal of Human Evolution 18(3): 235-68. http://dx.doi.org/10.1016/0047-2484(89) 90051-1

SAndGathe, D.M. \& B. Hayden. 2003. Did Neanderthals eat inner bark? Antiquity 77: 709-18. http://dx.doi.org/10.1017/S0003598X00061652

SCHÄppI, G.F., P.E. TAYlor, I.A. STAFF, J.M. Rolland \& C. Suphioglu. 1999. Immunologic significance of respirable atmospheric starch granules containing major birch allergen Bet v 1. Allergy 54: 478-83. http://dx.doi.org/10.1034/j.1398-9995.1999. 00838.x

Se, K., C. MeI, K. Inthavong \& J. Tu. 2010. Inhalability of micron particles through the nose and mouth. Inhalation Toxicology 22: 287-300. http://dx.doi.org/10.3109/08958370903295204

Sмith, F.H., M.O. SмiтH \& R. Schmitz. 2006. Human skeletal remains from the 1997 and 2000 excavations of cave deposits derived from the Kleine Feldhofer Grotte in the Neander Valley, Germany, in R.W. Schmitz (ed.) Neanderthal 1856-2006: 118-208. Mainz: von Zabern.

THIEME, H. 1997. Lower Palaeolithic hunting spears from Germany. Nature 385: 807-10. http://dx.doi.org/10.1038/385807a0

Ungar, P. S., F.E. GRINE, M.F. TEAFORD \& A. PÉrez-PÉREZ. 2001. A review of interproximal wear grooves on fossil hominin teeth with new evidence from Olduvai Gorge. Archives of Oral Biology 46: 285-92. http://dx.doi.org/10.1016/ S0003-9969(00)00128-X

URBANOWSKI, M., P. SOCHA, P. DĄBROWSKI, W. NOWACZEWSKA, A. SADAKIERSKA-CHUdY, T. Dobosz, K. STEFANIAK \& A. NADACHOWSKI. 2010. The first Neanderthal tooth found north of the Carpathian Mountains. Naturwissenschaften 97: 411-15. http://dx.doi.org/10.1007/s00114-010-0646-2

Volpato, V., R. Macchiarelli, D. Guatelli-Steinberg, I. Fiore, L. Bondioli \& D.W. Frayer. 2012. Hand to mouth in a Neandertal: right-handedness in Regourdou 1. PLoS ONE 7(8): e43949. http://dx.doi.org/10.1371/journal.pone.0043949

(C) Antiquity Publications Ltd, 2016 


\section{Neanderthals and trees}

WarinNer, C., J.F.M. ROdRIGUes, R. Vyas,

C. Trachsel, N. ShVed, J. Grossmann,

A. Radini, Y. Hancock, R.Y. Tito, S. Fiddyment,

C. Speller, J. Hendy, S. Charlton, H.U. Luder,

D.C. Salazar-García, E. Eppler, R. Seiler,

L.H. Hansen, J.A. Samaniego Castruita,

S. BARKOW-OSTERREICHER, K.Y. TEOH,

C.D. Kelstrup, J.V. Olsen, P. Nanni, T. Kawai,

E. Willerslev, C. von Mering, C.M. LeWIS JR,

M.J. COLLins, M.T.P. GILbERT, F. RƯHLI \&

E. CAPPELLINI. 2014. Pathogens and host immunity in the ancient human oral cavity. Nature Genetics

46: 336-44. http://dx.doi.org/10.1038/ng.2906

Weslowski, V., S.M. FerRAZ MendonçA De SoUZA,

K.J. Reinhard \& G. CeCCANTINI. 2010.

Evaluating microfossil content of dental calculus

from Brazilian sambaquis. Journal of Archaeological

Science 37: 1326-38.

http://dx.doi.org/10.1016/j.jas.2009.12.037
WoOd, R.E., T.F.G. Higham, T. DE TORRES,

N. Tisnérat-Laborde, H. Valladas, J.E. Ortiz,

C. Lalueza-FoX, S. SÁNCHEZ-Moral, J.C. Cañaveras, A. Rosas, D. Santamaría \& M. DE LA Rasilla. 2013. A new date for the Neanderthals from El Sidrón cave (Asturias, northern Spain). Archaeometry 55: 148-58. http://dx.doi.org/10.1111/j.1475-4754. 2012.00671.x

ZaCKRisson, O., L. OSTLund, O. Korhonen \& I. Bergman. 2000. The ancient use of Pinus sylvestris L. (Scots pine) inner bark by Sami people in northern Sweden, related to cultural and ecological factors. Vegetation History and Archaeobotany 9: 99-109. http://dx.doi.org/10.1007/BF01300060

Received: 22 January 2015; Accepted: 28 April 2015; Revised: 2 May 2015 